\title{
Life as IAU General Secretary
}

\author{
Derek McNally \\ School Physics, Astronomy and Mathematics, University of Hertfordshire, \\ Hatfield AL10 9AB, UK \\ email: D.McNally@herts.ac.uk
}

\begin{abstract}
In this paper I discuss the general role of the IAU General Secretary, and reminisce on the XXIst IAU General Assembly in Buenos Aires, Argentina in 1991, where a fire disrupted proceedings on the final days.
\end{abstract}

Keywords. IAU General Secretary, IAU General Assembly, XXIst GA in Argentina (1991)

It came as something of a surprise to be invited to serve as IAU General Secretary a bolt from the blue! I also had other affiliations with the IAU: Education, Interstellar Matter, and modelling (numerically) star formation and protecting observatory sites. The latter required a great deal of attention at all wavelengths.

I will not bore you with the basic duties of a General Secretary - keeping track of finances, keeping in touch with astronomical countries, dealing with IAU publications and, of course, planning and organising the triennial meeting. General secretaries spend the first three years learning the "trade", then three years as General Secretary and a final three years as advisor to the incoming General Secretary - the best bit!

General Secretaries tend to refer to the triennial General Assembly as "my General Assembly", which illustrates well the attention astronomers give to their science and which marks them out from many of the other scientific unions founded at the end of the First World War. The General Assembly is where you talk astronomy and only astronomy (admittedly an easy thing for astronomers to do).

"My GA" was to be held in Argentina - just a short time after the Anglo-Argentinian "upset". I had to meet President Menem in the company of several senior Argentinian astronomers to discuss the opening of the General Assembly, as he had agreed to welcome the world's astronomers. As he did not speak English and I did not speak Spanish, I had the pleasure of meeting his translator - Mrs Brown. Her English was impeccable - she spoke very like UK TV announcers when they first came on the air. At the Opening Ceremony she translated the President's welcome. She discussed his welcome speech with me as he was likely to mention "astrology" rather than "astrophysics". She considered this might give some offence to the astronomical community - quite rightly. So we agreed she would adjust the wording accordingly. Only one Spanish IAU member picked up that the President had said "astrology". I truthfully told him that I had not noticed, as I do not speak Spanish, and as Mrs Brown had translated it as "astrophysics". (Mrs Brown was a descendant of British engineers who built the Argentinian railways. They still play cricket and enjoy formal afternoon teas!)

I was somewhat apprehensive to be visiting Argentina so close to the end of the recent war with the UK. But I had no need of such worries - I was very kindly received by all whom I met. (I was just a little given to making sure all those I met knew that I was born and educated in Northern Ireland.) 
One of the duties of the AGS is to ensure that nothing of a political matter occurred during the AGM - e.g. political posters, non-astronomical posters and similar matters. But such items rarely occurred. As the triennial meeting is organised well in advance, the GS visits the country in which the meeting will be held to see that all agreed facilities are available. This gives an opportunity to meet the local astronomers on their home ground. The range of astronomical observation is remarkable and a splendid opportunity to meet with activities one might not otherwise encounter. A very useful broadening of the mind. But sometimes the GS has to take difficult actions when trying to advise members that once the programme for the meeting is full and no further papers can be accepted. Sometimes a new meeting is wanted during the course of the GA but cannot at that stage be accepted. I had serious difficulties with our women astronomers during the course of the General Assembly. However, all our meeting rooms were in active use. They were not best pleased when I offered to book a room for them during the evening eventually agreement was reached and now there has been an evening meeting for women astronomers (who do not mind male astronomers joining them) at each General Assembly. Unfortunately, having a fondness for cake, I have not yet been able to attend any of their evening meetings!

My General Assembly was running very smoothly until the day before the final day of the Meeting for that all important meeting of the General Assembly which deals with the state of the Union. On our way to breakfast that morning we noticed smoke rising from the direction of our meeting place in use for the lectures of interest for all astronomers, but it seemed unlikely our meeting place would be on fire. However, IT WAS!. What was going to happen to the most important part of the meeting - namely the first images taken from space, plus finalisation of other important administrative issues?

Next day I had to give the summary of financial and scientific activities for the approval of the astronomical community. And of course there were any remaining scientific meetings scheduled for that final day. However, our local contact - Juan O'Farell - sprang into action. It took Juan one hour to find enough meeting rooms for all but one meeting (a small one for Positional Astronomy - who adjourned to a local hostelry). To say it was the worst day of my life is a gross understatement. Fortunately, my wife had come with me to Argentina and was excellent in helping me get everyone back to their meetings, and keeping me sane. Patrick Moore sneaked in unnoticed by the fire crew to save his material for the final issue of the Meeting Daily Newspaper, which he was editing, and the final issue was ready and waiting for us on the final day! We had our large meeting room available next day and were able to conclude the conference in good order - even if the theatre smelt a little of smoke! I was then advisor for the incoming GS and my wife and I could spend a little time enjoying the sights of Argentina.

I hope that the fire will remain unique in the history of IAU Meetings of the future. You might even say my GS ended in a blaze of. . . well, hardly glory. 